\title{
Development of Course Teaching Materials Geography of Disaster Through the 4-D Model
}

\author{
Dian Ayu Larasati ${ }^{1, *}$, Nugroho Hari Purnomo ${ }^{2}$, Ketut Prasetya ${ }^{3}$ \\ 1,2,3Geography Education Department Universitas Negeri Surabaya, Surabaya, \\ Indonesia
}

*Corresponding Author. Email: dianlarasati@unesa.ac.id

\begin{abstract}
There are no specific teaching materials that accommodate student learning needs, and learning materials are still scattered in various sources. This condition occurs in the Geography of Disaster course, which so far there is no teaching material. Therefore, it is necessary to study textbooks for the Geography of Disaster as an alternative to find a way out in overcoming and making it easier for students to study these subjects, the purpose of this research and development is to "develop teaching materials for the Geography of Disasters based on experience to improve student learning competencies". This research is a development research. This study aims to develop and produce learning materials in the form of textbooks for teaching and learning strategies courses, especially on the subject of cooperative learning strategies. The development of constructivist learning tools assisted by textbooks with the 4-D model is quite effective in increasing student motivation and participation to be actively involved in the learning process compared to conventional learning. As many as $86.75 \%$ of students are actively involved in cooperative learning assisted by textbooks while in conventional learning the activeness of students is $63.25 \%$.
\end{abstract}

Keywords: 4-D Model, Learning, Geography of Disaster

\section{INTRODUCTION}

Teaching materials have many roles, namely helping lecturers implement the curriculum, guidance in determining learning methods, providing opportunities for students to repeat or learn new lessons, and provide continuity of lessons even though lecturers change [1]. The gap between the desire to improve the quality of learning and the availability of teaching materials is a problem in realizing quality lectures, moreover it is difficult to find Disaster Geography books on the market both in Indonesian and in foreign languages.

Teaching materials developed for interactive learning are very important. This refers to the function of teaching materials as 1) a guide for lecturers to direct all their activities in the learning process, as well as a substance of competence that should be mastered by students, 2) a guide for students who will direct all their activities in the learning process as well as a substance of competence that should be studied and mastered, 3) evaluation tools for achievement/mastery of learning outcomes.
[2] states that teaching materials that can develop learning experiences are informative teaching materials (informing learning objectives), there are instructional (for face-to-face learning and practice), formulating clear learning experiences), motivation, exploration to help students make discoveries. new to learning. Furthermore, [3], stated that the ideal teaching materials are teaching materials that can provide information and learning experiences and are developed with good designs and features.

Based on this fact, so that students can gain experience in designing learning and achievingpedagogic competence in learning, it is necessary tomake efforts to improve the learning of Disaster Geography courses. Considering the background that thelearning of Disaster Geography courses must at least: 1) be able to provide students with opportunities to study Disaster Geography in general whenever needed; 2) can be repeated by the students themselves until the studentsunderstand; 3) able to provide feedback quickly on student responses; and 4) interactive and not boring learning; and able to develop student competence as a whole. One solution that can be used for this purpose is 
the development of teaching materials for teaching Geography of Disasters that are experience-based and can be used by students to learn in order to achieve full competence. Based on the above background, the purpose of this research and development is to "develop experience-based Disaster Geography teaching materials to improve student learning competencies"

\section{METHODS}

This research is a development research. This study aims to develop and produce learning materials in the form of textbooks for the Geography of Disaster course.

\subsection{Research Development Procedure}

It has been mentioned in the previous chapter that the learning device development model used in this research is the development model developed by Thiagarajan, Semmel and Semmel which consists of the definition stage, the design stage, and the development stage[4].

\subsection{Expert Validation}

Activities at this stage are expert assessments, and field trials. Suggestions from the validators are used as the basis for the revision of the development tools carried out. Expert validation includes[5]:

1) The contents of the textbook are in accordance with the subject matter and the objectives to be measured.

2) Language, including:

a) Do the sentences on the learning device use good and correct language.

b) Does the sentence on the learning device not cause double interpretation?

\subsection{Trial}

\section{1) Learning Device Trial}

The trial of learning tools in the classroom aims to determine the clarity, legibility, and compatibility between the time planned in the lesson plan and its implementation. The results obtained from this trial are used for revision of learning devices.

\section{2) Trial Subject}

The trial of this learning device was carried out on semester III students of the Social Sciences Education Department Class A and B, Faculty of Social Sciences and Law, State University of Surabaya.

3) Product Development Trial Design

Product development trials were carried out using a two-group pretest-posttest design, which can be described in the following scheme:

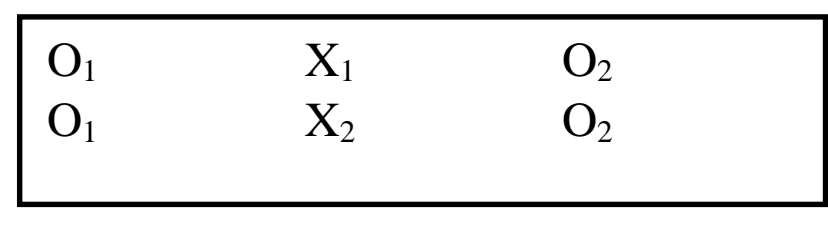

Description: $\quad \mathrm{O} 1=$ initial test $($ pretest)

$\mathrm{X} 1=$ control class (without the use of learning textbooks)

$\mathrm{X} 2$ = treatment (use of learning

textbooks)

$\mathrm{O} 2$ = final test (posttest)

$\mathrm{O} 1=\mathrm{O} 2$

\section{RESULTS AND DISCUSSION}

\subsection{Description Of The Defining Stage}

\subsubsection{Early-late analysis}

At this stage the researchers found that so far learning activities tend to be one-way, lecturer- student interactions. Lecturers explain the material using the lecture method, and students listen or takenotes[6]. This of course results in students being passive in participating in learning activities. The learning tools designed also do not contain constructivist learning. Learning activities that are applied tend to be classical in nature and do not involve student activities in groups, even though this is important to train students' social skills. Thisproblem, as an alternative, can be overcome bydesigning learning tools that contain constructivist understanding with the help of textbooks as learningmaterials[7]

\subsubsection{Student Analysis}

Students who become subjects in this study have diverse characteristics and also different socio- economic backgrounds. Likewise, if viewed from an academic ability, the level of intelligence is not much different in each class, because students in each class in the Geography Education Department have random input, where students are accepted using the SBMPTN, SNMPTN, Bidik Misi, as wellas Independent Path[8].

\subsubsection{Material Analysis}

The material taught in this study is a Statisticscourse with basic statistical material. The selection of materials is based on the purpose of this research, namely the development of teaching materials for Disaster Geography[9] 


\subsection{Description Of The Result Of The Design (Design)}

\subsubsection{Test Compilation}

The preparation of the test is preceded by compilinga test grid based on the specifications of the learningobjectives. That is, the test grid is a map of the distribution of items that have been prepared so that with these items it is expected that the level of test quality will be good. The tests developed were pre-test and post-test. Pre-test is given to students at thebeginning of learning activities and post-test at the end of the meeting[10]

\subsubsection{Media Selection}

The learning media used are textbooks. This textbook is designed specifically for student learning materials for 2 face-to-face meetings

\subsection{Description of The Result of The Development Stage (Develop)}

\subsubsection{Expert validation}

Expert validation is very important to determine whether or not the development product is suitable for use in trials in the experimental class. Of coursethis feasibility is with the need for revision of the intended learning materials or textbooks[11]

In stage 1 validation, there are several suggestions from the validator to make improvements, especially those related to format, namelyconsiderations between text and illustrations as well as choosing the type and size of letters. After improvements have been made, in stage 2 validation, results are obtained in the "good" category so that the product can be used as learningmaterial in the Geography of Disaster course[12].

It can be explained that the results of the validationat stage 1 generally obtained the category of "not good" textbooks, then after improvements were made, stage 2 obtained the results of developing textbooks that were in the "good" category so that the product could be used as learning material in theGeography of Disaster course.

\subsubsection{Product Trial}

The trial of learning tools was carried out in the 2018 class of the Social Sciences Education S1Study Program, which amounted to 84 people. Furthermore, the determination of product trials wascarried out randomly and in the end class $\mathrm{A}$ was chosen as the experimental class and class B as the control class[13]

\subsubsection{Test validity}

Based on the product moment correlation formula, the validity of each test item is obtained as follows (the calculations can be seen in the Appendix).

Table 1. The results of the analysis of the validity of the test items

\begin{tabular}{|c|c|c|}
\hline No. & Koef. Validity & Validity Level \\
\hline 1 & 0.712 & High \\
\hline 2 & 0.762 & High \\
\hline 3 & 0.726 & High \\
\hline 4 & 0.797 & High \\
\hline 5 & 0.508 & sufficient \\
\hline 6 & 0.795 & High \\
\hline 7 & 0.728 & High \\
\hline 8 & 0.832 & High \\
\hline 9 & 0.534 & sufficient \\
\hline 10 & 0.818 & High \\
\hline
\end{tabular}

Based on the data in the table above, the level of validity of each test item is mostly in the highcategory and only a few in the sufficient category. Thus, all the test items can be said to be valid so thatthey are suitable for use without revision

\subsubsection{Reliability}

Based on the calculation results obtained by the reliability coefficient $\alpha=0.822$. This means that thereliability of the learning outcomes test instrument developed is included in the "very high" category. Thus, the test instrument can be said to be reliable and can be used without revision to measure the level of student mastery of the material. 


\section{DATA ANALYSIS ANDINTERPRETATION}

\subsection{Student Activities}

The results of observations on student activities in cooperative learning who use textbooks and those who do not use textbooks, can be seen in the following table
The pre-test and post-test values in the experimentalclass and control class after going through the pairedsamples ttest can be explained that there is a difference between the pre-test and post-test results

Table 2. Student Activity Level

\begin{tabular}{|c|l|c|c|c|c|}
\hline NO & \multicolumn{1}{|c|}{ Observational aspect } & $\begin{array}{c}\text { 1st } \\
\text { meeting } \\
(\mathbf{\%})\end{array}$ & $\begin{array}{c}\text { 2nd } \\
\text { meeting } \\
(\mathbf{\%})\end{array}$ & $\begin{array}{c}\text { 3rd } \\
\text { meeting } \\
(\mathbf{\%})\end{array}$ & $\begin{array}{c}\text { Averag } \\
\mathbf{e}(\mathbf{\%})\end{array}$ \\
\hline 1 & Express your ideas and opinions & 70 & 73 & 80 & 74 \\
\hline 2 & Ask & 84 & 82 & 85 & 84 \\
\hline 3 & Using textbooks & 100 & 100 & 100 & 100 \\
\hline 4 & Doing assignments on time & 82 & 85 & 100 & 89 \\
\hline \multicolumn{2}{|c|}{ Amount } & & & 86.75 \\
\hline
\end{tabular}

Table 3. The level of student activity in the control class

\begin{tabular}{|c|l|c|c|c|c|}
\hline NO & \multicolumn{1}{|c|}{ Observational aspect } & $\begin{array}{c}\text { 1st meeting } \\
(\mathbf{\%})\end{array}$ & $\begin{array}{c}\text { 2nd meeting } \\
(\mathbf{\%})\end{array}$ & $\begin{array}{c}\text { 3rd } \\
\text { meeting } \\
(\mathbf{\%})\end{array}$ & $\begin{array}{c}\text { Average } \\
(\mathbf{\%})\end{array}$ \\
\hline 1 & Express your ideas and opinions & 75 & 80 & 82 & 79 \\
\hline 2 & Ask & 76 & 80 & 75 & 77 \\
\hline 3 & Using textbooks & 20 & 50 & 40 & 37 \\
\hline 4 & Doing assignments on time & 60 & 70 & 50 & 60 \\
\hline \multicolumn{2}{|c|}{ Amount } & & & 63.25 \\
\hline
\end{tabular}

From the two tables above, it can be explained that the activeness of students seen from the aspect of expressing their ideas and opinions, asking questions, obtaining teaching materials or materials and doing assignments between the experimental class and the control class is very much different. The participation rate of the experimental class (learning with textbooks) is $86.75 \%$ while for the control class (conventional learning) it is $63.25 \%$. The highest value that distinguishes the two is in thematerial aspect and doing the task[14]

\subsection{Description of the experimental result}

To answer the second research question, experimental research was conducted, namely comparing the control class with the class that received treatment. [15]Learning tools that havebeen developed, namely the final device, are used in this experiment. The research subjects consisted of one class that was randomly selected from twoparallel classes.
[16] with each sign $(\mathrm{p})=0.000$. Thus, there was a significant increase between the pre-test and post- test scores. The results of the $t$ test of two independent samples (independent sample t test)stated that there was a difference in the post-test value of the experimental class and the control class, with a sign value (p) of 0.000 . This means that thereis a significant effect of textbook-assisted cooperative learning on student learning outcomes. Thus, cooperative learning with the help of textbooks has been proven to be significant in improving student learning outcomes[17]

\subsection{Discussion}

Constructivist learning can be developed with a variety of learning strategies and one of them is cooperative learning. Cooperative learning is able to increase student participation to be active and directly involved in the learning process. This is in line with [18] opinion that constructivist learning is able to arouse students' awareness to express their ideas explicitly. 
The results[19] of textbook-assisted learning are not significantly different from conventional learning (although the results are better) because the media is actually just a tool, which cannot replace the role of the teacher in the classroom.[20] However, the results of the study show that using textbooks can create higher student motivation and learning participation. These findings indicate that students do not experience psychological pressure so that the courage to express their ideas will appear when learning to use textbooks.[21]

Textbooks can be printed teaching materials that are very economical and practical. It is said to be economical and practical because textbooks generally only contain summaries or conclusions or parts of important material so that students can immediately know the basics and important points in the material being studied using textbooks.[1]

Textbooks that contain important points from the subject matter being studied, if used, of course, will not create confusion for students in learning a material. The design of textbook teaching materials like this certainly makes student learning more guided, students know what to learn so they don't study materials that are not relevant to the subject or subject matter being studied using textbooks. [22]

\section{REFERENCES}

[1] M. N. Nasution, Manajemen Mutu Terpadu: Total Quality Management, Edisi Kedu. Bogor: Ghalia Indonesia, 2005.

[2] J. Feist, Teori Kepribadian, Buku I. Jakarta: Salemba Humanika, 2012.

[3] G. J. F. Feist, Jess., Teori Kepribadian, Buku II. Jakarta: Salemba Humanika, 2012.

[4] K. Kartini, Teori Kepribadian. Bandung: Mandar Maju, 2005.

[5] L. Roesminingsih dan Hadi Susarno, Teori dan Praktek Pendidikan. Surabaya: Lembaga Pengkajian dan Pengembangan Ilmu Pendidikan Unesa, 2013.

[6] A. Sobur, Psikologi Umum. Bandung: Pustaka Setia, 2010

[7] A. S. Heuken, Tantangan Membina Kepribadian:PedomanMengenal Diri. Yogyakarta: Kanisius, 1979.

[8] H. Agustiani, Psikologi perkembangan pendekatan ekologi kaitannya dengan konsep diri. Bandung: PT. Refika Aditama, 2016.

[9] E. B. Hurlock, Psikologi Perkembangan: Suatu Pendekatan Sepanjang Rentang Kehidupan, Edisi Keli. Jakarta: Erlangga, 1999.

[10] J. Rahmat, Psikologi Komunikasi. Bandung: Remaja Rosdakarya, 2000.
[11] Alwisol, Psikologi Kepribadian. Malang: Universitas Muhammadiyah Malang, 2005.

[12] A. Rini, Petunjuk mengarahkan Bakat Anak. Jakarta: Pustaka Mina, 2009.

[13] K. K. Metcalf; Criuckshank, Donald R.; Bainer Jenkins, Deborah., Perilaku Mengajar, Buku I. Jakarta: Salemba Empat, 2014.

[14] S. Dirgagunarsa, Pengantar Psikologi. Jakarta: Mutiara, 1998.

[15] S. dan Sundeen, Buku Keperawatan, Edisi 3. jakarta: EGC, 1998.

[16] and K. K. M. Criuckshank, Donald R., Bainer Jenkins, Deborah., Perilaku Mengajar, Buku II. Jakarta: Salemba Empat, 2014.

[17] D. Sousa, Bagaimana Otak yang Berbakat Belajar. Jakarta: PT Indeks, 2012.

[18] D. P. Nasional, Pendidikan Karakter Teori \& Aplikasi. jakarta: Direktorat Jenderal Manajemen Pendidikan dan Menengah Kementerian Pendidikan Nasional., 2010.

[19] L. Rose, Menggali Potensi Diri, Citra Pribadi Berkualitas. Jakarta: Pustaka kartini, 1996.

[20] R. Burns, Konsep Diri: Teori, Pengukuran, Perkembangan dan Perilaku. (alih bahasa: eddy). Jakarta: Arcan, 1993.

[21] B. Lucy, Mendidik sesuai dengan minat dan bakat anak (printing your children's). Jakarta: Pustaka, 2009.

[22] R. Arends, Learning to Teach. Jakarta: Ghalia Indonesia, 2001. 